\title{
THE UTILIZATION OF PICTURE AND PICTURE STRATEGY: An Effective Way to Improve EFL Students' Writing Ability in Madrasah Tsanawiyah
}

\author{
M. Arif Rahman Hakim', Tri Nur Susanti², Asiyah³, Mohamad Jafre Zainol Abidin 4 \\ 1,2,3 State Institute for Islamic Studies (IAIN) Bengkulu, Indonesia \\ Jl. Raden Patah Pagar Dewa, Bengkulu

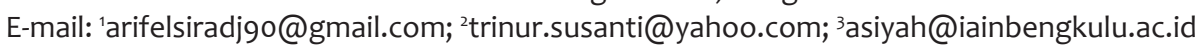 \\ ${ }^{4}$ Universiti Sains Malaysia (USM),Malaysia \\ Jl. 11800 Penang, Malaysia \\ E-mail: jafre@usm.my
}

\begin{abstract}
The aim of this study is to find out whether or not there was a significant difference between students who were taught using picture and picture strategy and that of those who were not in writing recount text. The study employed a quasi-experimental study. The population in this study were the second grade students of Madrasah Tsanawiyah in Bengkulu city, Indonesia with a total number are 89 students. Out of this population, 60 students were taken as the sample. They are divided into two groups; experiement and control group, which consisted of 30 students for each group. The data were collected by using writing test. The data obtained were analyzed by using $t$ - test formula. The data were found that the result of $t_{\text {- }}$ count post-test (6.34) was higher than $t_{\text {table }}$ (2.00) with $\alpha=5 \%$ and $d f=58$. The finding of this research shows that there is a significant difference between students in Madrasah Tsanawiyah who are taught using picture and picture strategy and that of those who are not. Based on the result on the study, picture and picture strategy can improve students' writing achievement in writing recount text evidently
\end{abstract}

Keywords: recount text; picture and picture strategy; Indonesian Learners.

Abstrak: Tujuan dari penelitian ini adalah untuk mengetahui apakah terdapat perbedaan yang signifikan antara siswa yang diajar menggunakan strategi gambar dan gambar dan siswa yang tidak dalam menulis teks pengalaman. Penelitian ini menggunakan studi quasi-eksperimental. Populasi dari penelitian ini adalah para siswa kelas dua Madrasah Tsanawiyah di kota Bengkulu, Indonesia dengan jumlah total 89 siswa. Dari populasi ini, 60 siswa diambil sebagai sampel. Mereka dibagi menjadi dua kelompok: grup eksperimen dan kontrol , yang terdiri dari 30 siswa untuk setiap kelompok. Data dikumpulkan dengan menggunakan tes menulis. Data yang diperoleh dianalisis dengan menggunakan rumus t-test. Data yang telah dihasilkan yaitu hasil dari t-hitung dari tes akhir $(6,34)$ lebih tinggi dibandingkan t-tabel $(2,00)$ dengan $a=5 \% \mathrm{dan} d f=58$. Temuan dari penelitian ini menunjukkan bahwa terdapat perbedaan yang signifikan antara siswa di Madrasah Tsanawiyah yang diajar menggunakan strategi picture and picture dengan mereka yang tidak. Berdasarkan hasil pada penelitian, strategi picture and picture secara jelas dapat meningkatkan hasil pencapaian para siswa dalam menulis teks pengalaman.

Kata kunci: teks pengalaman; strategi gambar dan gambar; siswa Indonesia.

\section{Introduction}

The most serious writing problems for EFL students arise when they tried to transform a native language sentence word by word into a foreign language equivalent. ${ }^{1}$ They are confused

' Dwi Ariningsih, The effectiveness of using picture series to improve the students' writing skill viewed from their learning motivation (An Experimental Study in the Seventh Grade of SMPN 1 Tanjunganom Nganjuk in the Academic Year 2008/2009), how to transfer what on their mind are into English. These problems always happen because of the lack of vocabulary and other factors, so it makes their words are very limited in writing. ${ }^{2}$ Moreover, strategy implemented by teacher in

(Surakarta: UNS, 2010), p. 29

${ }^{2}$ Andri Saputra \& M. Arif Rahman Hakim. "The Usage of Cohesive Devices by High-Achieving EFL Students in Writing Argumentative Essays", Indonesian TESOL Journal vol.2, no. 1(2020), p. 44 
the teaching and learning process also becomes the problem. These conditions also happened in Madrasah Tsanawiyah or Islamic junior high school students in Indonesia. According to the observation in some Madrasah Tsanawiyah in Bengkulu, Indonesia, researchers found that the students have a lot of problems in writing, especially when they got recount text topic. In the normal teaching learning process, the teacher always used a general course textbook in teaching writing and without additional supporting media. This happened because of the availability of facilities in the schools to support the teaching and learning process were not sufficient. Furthermore, according to teachers' statement, most of the students had low motivation in composing a story. They also faced a problem of vocabulary mastery. The teachers also realized that the teaching learning activities in their class still used an old fashioned way.

Based on the problem above, researchers concluded that the teachers need a new strategy to help their students in study writing recount text. Actually there are many kinds of strategies that can be applied in teaching learning activities especially in the context of teaching writing. But in in this case, researchers have to choose a strategy that suitable with the syllabus, curriculum and students condition in Madrasah Tsanawiyah. The application of strategy in teaching genre, especially recount text has variety effects for the students. It is the job of researchers to decide an appropriate strategy and asked the teacher to use in teaching learning process. It aims to get better achievement and also good responds from the student in learning activity.

Based on some discussion, researchers decided to use a quasi experimental research design by applying picture and picture strategy as the treatment for students in learning writing reclunt text. Besides based on the curriculum, syllabus and discussion, this learning strategy was chosen for some reasons: students' faster capture of teaching materials when the teacher shows some additional media including pictures in the material being studied; this strategy is expected can increase perceptibility or students' thinking because the teacher makes the students to analyze an existing image; it expected can increase the responsibility of students because the strategy will make teacher ask to their students why they sort the pictures; and learning will be more memorable because students can observe directly the picture that has been prepared by the teacher. Based on varous explanation above, at the end of this study, researchers wanted to find out whether or not there was a significant difference between students who were taught using picture and picture strategy and that of those who were not.

\section{Literature Review}

Writing involves communicating a message with a sign or symbol on a page. It needs to make series of words or sentences in writing process to communicate in the written language. ${ }^{3}$ As one of four language skills, writing skill is complex and sometimes difficult to teach ${ }^{4}$. It means that requiring mastery not only of grammatical and rhetorical devices but also of conceptual and judgmental elements. Furthermore, Harmer stated that writing is a way to produce language and express idea, feeling, and opinion ${ }^{5}$. It proves that writing is one of media communication through written language. It is very useful to send information or news to other people around the world.

As a written language, Nunan said that writing is a manual process of committing symbols (letters of the alphabet, etc.) to paper or a computer screen by manipulating a pencil, pen, or keys on a keyboard ${ }^{6}$. On the other hand, writing is a mental process of generating ideas and thinking about how to present them effectively in the form of a written text.

\section{Recount Text}

Recount is a kind of genre that has social function to retell events for the purpose of

\footnotetext{
3 Kremmel, Benjamin, Kathrin Eberharter, and Michael Maurer, "Righting Writing Practices?: An Exam Reform's Impact on L2 Writing Teaching and Assessment", The Politics of English Second Language Writing Assessment in Global Contexts, (Routledge, 2018), p. 130.

4 Mehmet Sercan Uztosun, "Writing English Language Tests (New Edition)", Eğitimde Kuram ve Uygulama, vol.2, no. 2 (2006), p. 119

5 Jeremy Harmer, "Review of "How to teach writing", Electronic Journal of Foreign Language Teaching vol.3, no. 2 (2006), p. 246

6 David Nunan, Teaching English to speakers of other languages: An introduction, (London: Routledge, 2015), p. 45
} 
informing or entertaining 7 . The tense that used in recount text is past tense. A recount recalls and reconstructs events, experiences and achievements from the past in a logical sequence of recounts will be purely informative, while others will aim to both inform and entertain.

In this case, Fitzsimmons et al stated that social purpose of recount is to tell what happened by retelling events in original sequence ${ }^{8}$. It is generally based on fact rather than fiction. We can look at the sample of recount in personal letters, police report, insurance claims, and incident reports.

\section{Picture and Picture}

Picture and picture is a learning strategy that uses picture and paired or sorted into logical sequence 9 . In operation the pictures are paired with each other or sorted into a logical sequence. Teachers as learning media in the class help students to think logically and systematically uses the picture.

According to Campbell and Gonzales, the use of pictures is very useful in the teaching process. ${ }^{10}$ Pictures contribute to improve the students' interest and motivation in the teaching learning process. It helps the students in developing ideas to write a text. Furthermore, sequences of picture can be kept as they are and used to contextualize a story or a description of a process.

From the explanation above, researchers concluded that picture and picture is a learning strategy that uses images and paired/ sorted into a logical sequence. By preparing pictures, the teacher can determine the ability of students to understand the main problem concept and trained students to think logically and systematically.

Based on some sources, researchers arranged some steps in doing picture and pictures strategy: teacher submits the aim of learning that will be

\footnotetext{
${ }^{7}$ Adin Fauzi, "The effect of edmodo on students' writing skill in recount text", International Journal of Pedagogy and Teacher Education, vol.1, no. 2 (2017), p. 73

${ }^{8}$ Fitzsimmons, P., P. Harris, B. McKenzie, and J. Turbill, Writing in the Primary School Years, (NSW: Social Science Press, 2003), p. 35

${ }_{9}$ Mukarto, Sujatmiko, S. M. Josephine, and W. Kriswara. English on sky 2, (Jakarta: Erlangga, 2007), p. 25

10 Campbell, Madeleine, and Laura González. "Wozu Image?"/What's the Point of Images? Exploring the Relation between Image and Text through Intersemiotic Translation and Its Embodied Experience", Open Cultural Studies, vol.2, no. 1 (2018), p. 686
}

achieved; teacher gives introductory material before activity; teacher provides pictures that will be used (relating to the material); teacher chooses the students in rotation to sort or pairing the pictures ${ }^{11}$; teacher gives a question about the reason in determining the sequences of pictures to the students ${ }^{12}$; from this reason, the teacher asks students to write recount.

\section{Method}

This study was conducted through quasiexperimental research design. This design is often used in classrooms when experimental and control groups are such naturally assembled group as intact classes, which may be similar ${ }^{13}$. Intact classes mean that the second grade students in the experimental group and the control group had the same competence, and the same English teacher.

According to Cohen, Manion and Morrison, this research design called pretest-posttest nonequivalent-groups design because two groups of experimental and control ${ }^{14}$ were involved in this study as presented in the following:

\begin{tabular}{|l|}
\hline Treatment: $\mathrm{O}_{1} \mathrm{X} \mathrm{O} 2$ \\
\hline Control: $\mathrm{O}_{3} \mathrm{O}_{4}$ \\
\hline
\end{tabular}

Where:

O1: Pretest in experimental group

O3: Pretest in control group

$\mathrm{X}$ : Treatments in experimental group

O2: Posttest in experimental group

O4: Posttest in control group

Population of this research are 89 students from second grade of Madrasah Tsanawiyah in Bengkulu, Indonesia. The researchers took two classes as the sample, and divided into two groups, 30 students for the experimental group and another 30 for the controlled group. The researcher took sample based on some factors: (1) the same competence and (2) taught by the

\footnotetext{
${ }^{11}$ Miftahul Huda, Model-Model Pengajaran: Isu-Isu Metodis dan Paradigmatis, (Yogyakarta: Pustaka Belajar, 2013), p. 239

${ }^{12}$ Agus Suprijono, Cooperative Learning; Teori dan Aplikasi Paikem, (Pustaka Pelajar: Yogyakarta, 2011), $5^{\text {th }}$ print, p. 125

${ }^{13}$ Delneshin Danaei, Hamid R. Jamali, Yazdan Mansourian, and Hassan Rastegarpour, Comparing reading comprehension between children reading augmented reality and print storybooks, (Computers \& Education, 2020), p. 103900

14 Louis Cohen, Lawrence Manion, and Keith Morrison, Research methods in education, (London: Routledge, 2013), p. 95
} 
same teacher. The researcher took the data from their English teacher based on their achievement from last semester.

In this study, researchers used writing test as an instrument to collect the data. The tests were in the essay form and addapted from Loveri ${ }^{15}$. The researchers gave writing test to the students in pre-test and post test to analyze their scores on content, organization, vocabulary, language use, and technically.

Researchers used statistical analysis with t-test and normalized gain for the data analysis stage in this study. It had purpose to test the significance of the gained mean score of the experiment and control group ${ }^{16}$. The formula for the manual calculation can be described as follows:

$$
t_{0}=\frac{M_{1}-M_{2}}{S E_{M 1}-M_{2}}
$$

$t_{0}$ : The value of "t observe"

$M_{1}$ : Mean of the difference of experiment class

$M_{2}$ : Mean of the difference of controlled class $S E_{M_{1}}$ : Standard error of experiment class

$\mathrm{SE}_{\mathrm{ML}_{2}}$ : Standard error of controlled class

\section{Result}

\section{Score Post Test}

Based on the result of this research, the post-test score was higher than the pre-test score. Graphically, the total score of students pre-test and post-test in the experiment class could be seen on figure below

Figure 1. Students' Score in Pre-test and Post-test (Experiment Group)

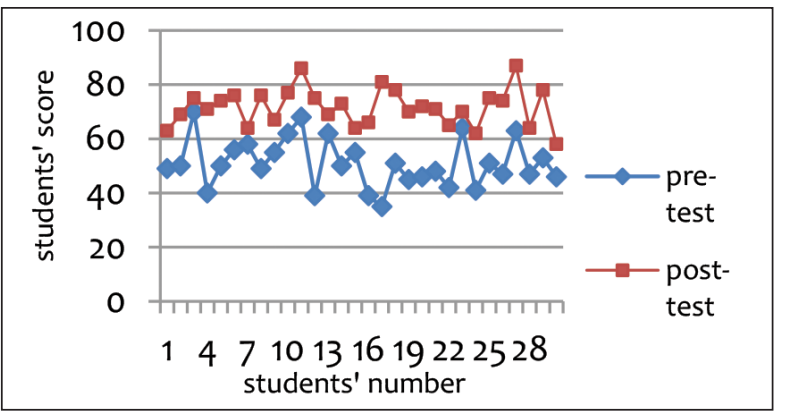

${ }^{15}$ Loveri, Ardilla, Developing English Grammar Worksheet of Recount Text for Eighth Grade Students of SMP N 17 Jambi, (Jambi: Repository UNJA, 2017), p. 60

${ }^{16}$ Chih-Pei, H. U., and Yan-Yi Chang. "John W. Creswell, research design: Qualitative, quantitative, and mixed methods approaches." Journal of Social and Administrative Sciences, vol. 4, no. 2 (2017), p. 205

\section{The Score Distribution in Experiment Class}

According to figure 1, the distribution of pretest and post-test scores in the experiment class, there was o (0\%) students in excellent category, o (0\%) students in very good category, o (0\%) students in good category, 7 (23.33\%) students in poor category, and 17 (56.67\%) students in very poor category. On the other hand, in post-test, there was o (0\%) students in excellent category, 3 (10\%) students in very good category, 14 (46.67\%) students in good category, $12(40 \%)$ students in fair, $1(3.33 \%)$ students in poor category, and 0 (0\%) students in very poor category.

\section{Score of Pre Test}

The analysis in control class showed that the post-test score and the pre-test scores were relatively same. The total score of students pretest and post-test in the control class can be seen on graphically below.

Figure 2. Students' Score in Pre-test and Post-test (Control Group)

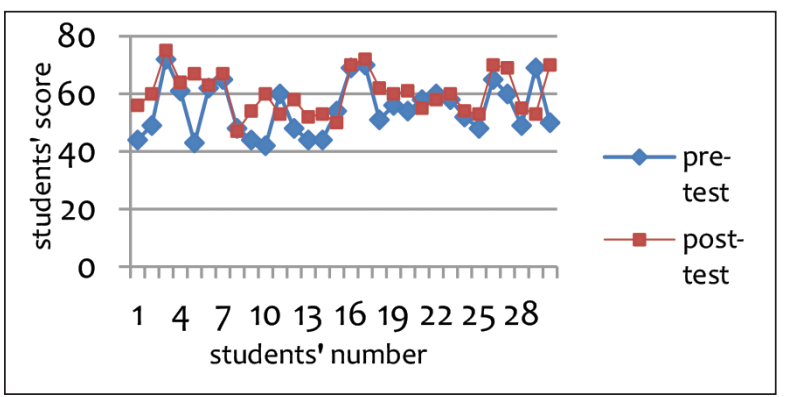

Based on the analysis of the result in pretest in control class, there was o (0\%) students in excellent category, o (0\%) students in very good category, 1 (3.33\%) student in good category, $7(23.33 \%)$ students in fair category, 10 (33.33\%) students in poor category, and $12(40 \%)$ students in very poor category. While, in post-test, there was 0 (0\%) students in excellent category, o (0\%) students in very good category, $2(6.67 \%)$ students in good category, 10 (33.33\%) students in fair category, 16 (53.33\%) students in poor category, and 2 (6.67\%) students in very poor category. The distribution of pre-test and post-test scores in the experiment class could be seen on table below.

\section{The Normality Data in Pre-test Group}

In analyzing the normality of the data test of pre-test scores, researchers used one-sample 
Kolmogorov-Smirnov test. The result of normality data of pre-test in the experiment class could be seen in table below.

Table 1. The Result of Normality Data of Pre-Test in Experiment Class

\begin{tabular}{llc}
\hline \multicolumn{2}{c}{ One-Sample Kolmogorov-Smirnov } & \multicolumn{1}{c}{$\begin{array}{c}\text { Pest } \\
\text { Pre-test } \\
\text { experiment }\end{array}$} \\
\hline $\mathrm{N}$ & \multicolumn{1}{c}{30} \\
\hline Normal Parameters ${ }^{\mathrm{a}, \mathrm{b}}$ & Mean & 51.03 \\
\cline { 2 - 3 } & Std.Deviation & 8.904 \\
\hline Most Extreme Differences & Absolute & .135 \\
\cline { 2 - 3 } & Positive & .135 \\
\cline { 2 - 3 } & Negative & -.091 \\
\hline Kolmogorov-Smirnov Z & & .738 \\
\hline Asymp. Sig. (2-tailed) & & .647 \\
\hline
\end{tabular}

The result showed that the significance value of experiment class pre-test score was 0.738. It meant that it was higher than the level significance (0.05). So, it could be assumed that the data were distributed normally.

Table 2. Normality Test of Pre-Test Score in Control Class

\begin{tabular}{llc}
\hline \multicolumn{3}{c}{ One-Sample Kolmogorov-Smirnov Test } \\
\hline \multirow{2}{*}{$\mathrm{N}$} & $\begin{array}{c}\text { Pretest } \\
\text { control }\end{array}$ \\
\hline \multirow{2}{*}{ Normal Parameters ${ }^{\mathrm{a}, \mathrm{b}}$} & 30 \\
\cline { 2 - 3 } & Mean & 54.97 \\
\cline { 2 - 3 } Most Extreme & Std. Deviation & 9.008 \\
\cline { 2 - 3 } Differences & Absolute & .113 \\
\cline { 2 - 3 } & Positive & .113 \\
\cline { 2 - 3 } Kolmogorov-Smirnov Z & Negative & -.079 \\
\hline Asymp. Sig. (2-tailed) & & .618 \\
\hline
\end{tabular}

The result showed that the significance value of control class pre-test score was 0.618. It meant that it was higher than the level significance (0.05). So, it could be assumed that the data were distributed normally.

The result of pre-test in experiment class and control class was almost similar where the pretest mean score of experiment class 51.03 (the average of students' mastery score was $51.03 \mathrm{x}$ $100 \%=51.03 \%$ ), and pre-test mean score of control class was 54.97 (the average of students' mastery score was $54.97 \times 100 \%=54.97 \%$ ). The category of students' achievement level was shown in the following table.
Table 3. Scale Interval Percentage of the Students' Achievement (Hakim, 2018)

\begin{tabular}{cc}
\hline Interval Percentage & Category \\
\hline $91-100 \%$ & Excellent \\
\hline $81-90 \%$ & Very Good \\
\hline $71-800 \%$ & Good \\
\hline $61-70 \%$ & Fair \\
\hline $51-60 \%$ & Poor \\
\hline$\leq 50 \%$ & Very Poor \\
\hline
\end{tabular}

Since the average of students' mastery in experiment class was $51.03 \%$ and in the control class was $54.97 \%$, it could be concluded that both classes were in poor category.

\section{The Normality Data in Post-test Group}

In analyzing the normality of the data test of post-test scores, the researcher used onesample Kolmogorov-Smirnov test. The result of normality data of post-test in the experiment class could be seen in table below.

Table 4. The Result of Normality Data of Post-Test Scores in Experiment Class

\begin{tabular}{llc}
\hline \multicolumn{2}{c}{ One-Sample Kolmogorov-Smirnov Test } \\
\hline \multirow{2}{*}{$\mathbf{N}$} & \multicolumn{1}{c}{$\begin{array}{c}\text { Pretest } \\
\text { control }\end{array}$} \\
\hline \multirow{2}{*}{ Normal Parameters ${ }^{\mathrm{a}, \mathrm{b}}$} & Mean & 30 \\
\cline { 2 - 3 } & Std. Deviation & 71.67 \\
\hline \multirow{2}{*}{ Most Extreme } & Absolute & 6.875 \\
\cline { 2 - 3 } Differences & Positive & .078 \\
\cline { 2 - 3 } & Negative & .078 \\
\hline Kolmogorov-Smirnov Z & & .066 \\
\hline Asymp. Sig. (2-tailed) & & .430 \\
\hline
\end{tabular}

The result showed that the significance value of experiment class post-test score was 0.430. It meant that it was higher than the level significance (0.05). So, it could be assumed that the data were distributed normally.

Table 5. The Result of Normality Data of Post-Test Score in Control Class

\begin{tabular}{llc}
\hline \multicolumn{3}{c}{ One-Sample Kolmogorov-Smirnov Test } \\
\hline \multirow{2}{*}{$\mathbf{N}$} & \multicolumn{1}{c}{$\begin{array}{c}\text { Post-test } \\
\text { Control }\end{array}$} \\
\hline \multirow{2}{*}{ Normal Parameters ${ }^{\mathrm{a}, \mathrm{b}}$} & Mean & 30 \\
\cline { 2 - 3 } & Std. Deviation & 60.03 \\
\hline \multirow{3}{*}{ Most Extreme Differences } & Absolute & 7.318 \\
\cline { 2 - 3 } & Positive & .121 \\
\cline { 2 - 3 } & Negative & .121 \\
\hline Kolmogorov-Smirnov Z & & .096 \\
\hline Asymp. Sig. (2-tailed) & & .662 \\
\hline
\end{tabular}


The result showed that the significance value of control class post-test score was 0.662. It meant that it was higher than the level significance (0.05). So, it could be assumed that the data were distributed normally.

The result of post-test in experiment class and control class was different where the posttest mean score of experiment class 71.67 (the average of students' mastery score was 71.67 $x 100 \%=71.67 \%$ ), and post-test mean score of control class was 60.03 (the average of students' mastery score was $60.03 \times 100 \%=$ $60.03 \%)$. Based on the table of scale interval percentage of the students' achievement, the category of students' achievement of experiment class and control class was different. Based on the scale interval percentage of the students' achievement (Hakim, 2018), category of experiment class increased in good while in control class was in poor.

\section{Result of Homogeneity of Variences of Pre-Test Group}

Levene Statistics in IBM SPSS 22 was used to analyze the homogeneity of variances of experiment and control class pre-test score. The result could be seen in the table below.

Table 6. Test of Homogeneity of Variances in Pre-test

\begin{tabular}{cccc}
\hline Levene Statistic & df1 & df2 & Sig. \\
\hline 2.436 & 7 & 12 & .084 \\
\hline
\end{tabular}

From the SPSS output in table 4.8 above, it could be seen that Levene's test was 0.084 , and it was bigger than $0.05(0.084>0.05)$. In other words, it could be concluded that the data variances were homogeneous or equal.

\section{Result of Homogeneity of Variences of Post-Test Group}

Table 7. Test of Homogeneity of Variances in Post test

\begin{tabular}{cccc}
\hline $\begin{array}{c}\text { Levene } \\
\text { Statistic }\end{array}$ & df1 & df2 & Sig. \\
\hline .470 & 6 & 12 & .818 \\
\hline
\end{tabular}

From the SPSS output in table 4.9 above, it could be seen that Levine's test was 0.818 , and it was bigger than $0.05(0.818>0.05)$. In other words, it could be concluded that the data variances were homogeneous or equal.

\section{Statistical Analysis Result}

In order to verify the hypothesis proposed, the statistical analysis were applied. The t-test used independent sample t-test where independent sample t-test (SPSS) 22 program was applied in order to find out whether or not there was significant difference in students' writing ability between the experiment class and the control class.

\section{Independent Sample T-Test Analysis of Pre-Test Group}

Table 8. Group Statistic Independent Sample T-Test (Pre-test)

\begin{tabular}{|c|c|c|c|c|c|}
\hline \multicolumn{6}{|c|}{ Group Statistics } \\
\hline & Group & $\mathbf{N}$ & Mean & $\begin{array}{c}\text { Std. } \\
\text { Deviation }\end{array}$ & $\begin{array}{l}\text { Std. } \\
\text { Error } \\
\text { Mean }\end{array}$ \\
\hline \multirow{2}{*}{$\begin{array}{l}\text { Pre- } \\
\text { test }\end{array}$} & Experiment & 30 & 51.03 & 8.904 & 1.626 \\
\hline & Control & 30 & 54.97 & 9.008 & 1.645 \\
\hline
\end{tabular}

Table 9. Analysis Independent Sample T-Test (Pre-test)

\begin{tabular}{|c|c|c|c|c|c|c|c|c|c|c|}
\hline \multicolumn{11}{|c|}{ Independent Samples Test } \\
\hline & & $\begin{array}{l}\text { Leve } \\
\text { Test } \\
\text { Equal } \\
\text { Varia }\end{array}$ & $\begin{array}{l}\text { ne's } \\
\text { for } \\
\text { ty of } \\
\text { nces }\end{array}$ & & \multicolumn{6}{|c|}{$\mathrm{t}$-test for Equality of Means } \\
\hline & & \multirow[t]{2}{*}{$\mathrm{F}$} & \multirow[t]{2}{*}{ Sig. } & \multirow[t]{2}{*}{$\mathrm{t}$} & \multirow[t]{2}{*}{ Df } & \multirow{2}{*}{$\begin{array}{l}\text { Sig. (2- } \\
\text { tailed) }\end{array}$} & \multirow{2}{*}{$\begin{array}{c}\text { Mean } \\
\text { Difference }\end{array}$} & \multirow{2}{*}{$\begin{array}{l}\text { Std. } \\
\text { Error } \\
\text { Differenc } \\
\text { e }\end{array}$} & \multicolumn{2}{|c|}{$\begin{array}{l}95 \% \text { Confidence } \\
\text { Interval of the } \\
\text { Difference }\end{array}$} \\
\hline & & & & & & & & & $\begin{array}{c}\text { Lowe } \\
\mathrm{r}\end{array}$ & Upper \\
\hline \multirow[t]{2}{*}{$\begin{array}{l}\text { Pre- } \\
\text { test }\end{array}$} & $\begin{array}{l}\text { Equal } \\
\text { variances } \\
\text { assumed }\end{array}$ & .321 & .573 & 1.701 & 58 & .094 & -3.933 & 2.312 & -8.562 & .695 \\
\hline & $\begin{array}{l}\text { Equal } \\
\text { variances } \\
\text { not } \\
\text { assumed }\end{array}$ & & & 1.701 & 57.992 & .094 & -3.933 & 2.312 & -8.562 & .695 \\
\hline
\end{tabular}

Based on the table above, the t-table was found 2.0 (level significance $=0.05, \mathrm{df}=60-2=$ 58), two tailed of test. The t-count was compared to the $\mathrm{t}$-table, and $\mathrm{t}$-count was found smaller than t-table $(-1.701<2.0)$. So, it could be concluded that $H_{a}$ was rejected and $H_{0}$ was accepted. In other words, there was no significant difference in pre test average score before treatment being done between experiment class and control class. Moreover, based on the result of pre-test, students' ability in writing recount text was still poor. It could be seen from mean score of experiment class which was only 51.03 and control class which was only 54.97. From this result, the researcher concluded that the average score for both classes were poor; two groups had similar background knowledge. 
Independent Sample T-Test Analysis of Post-Test Group

Table 10. Group Statistic Independent Sample T-Test (Post-test) Group Statistics

\begin{tabular}{cccccc}
\hline Group & N & Mean & $\begin{array}{c}\text { Std. } \\
\text { Deviation }\end{array}$ & $\begin{array}{c}\text { Std. } \\
\text { Error } \\
\text { Mean }\end{array}$ \\
\hline $\begin{array}{c}\text { Post- } \\
\text { test }\end{array}$ & Experiment & 30 & 71.67 & 6.875 & 1.255 \\
\cline { 2 - 6 } & Control & 30 & 60.03 & 7.318 & 1.336 \\
\hline
\end{tabular}

Table 11. Analysis Independent Sample T-Test (Post-test)

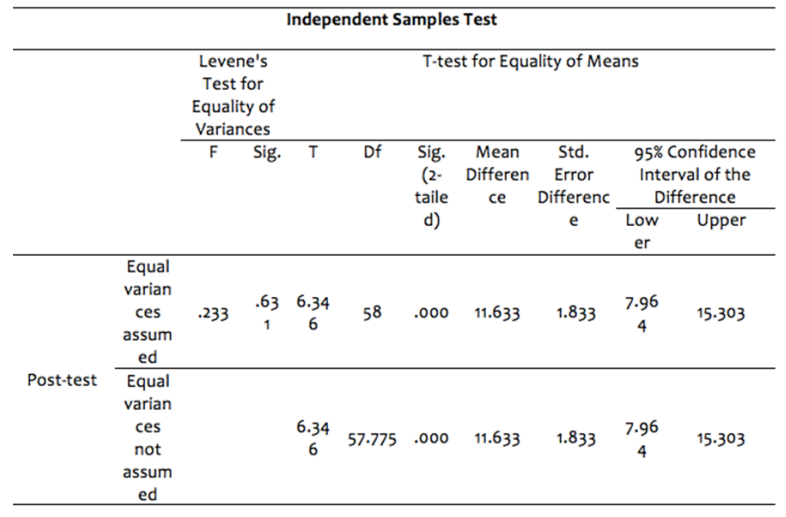

Based on the table above, the $\mathrm{t}$-table was found 2.0 (level significance $=0.05, \mathrm{df}=60-2=$ 58). The t-count was compared to the $t$-table, and $\mathrm{t}$-count was found bigger than $\mathrm{t}$-table $(6.346 \geq$ 2.0) and Sig. (2-tailed) was smaller than 0.05 (0.00 $<0.05$ ). So, it could be concluded that $\mathrm{H}_{\mathrm{a}}$ was accepted and $\mathrm{H}_{\mathrm{o}}$ was rejected. In other words, in post-test, there was significant difference of average score after treatment in both experiment class and control class where experiment class was taught by Picture and Picture Strategy while control class was taught without using Picture and Picture Strategy, or by using conventional strategy. In addition, students' writing ability in experiment class improved to good while control class was still in average category. However, there was still a significant difference between both classes' mean score. It can be seen from mean score of both experiment class and control class, which was 71.7 and 60.0 for each. In conclusion, picture and picture strategy improved students' ability in writing recount text.

\section{Discussion}

In the process of teaching learning activities during the treatment in experimental class, researchers found four changes in students' performance: (a) It trained the students to think logical and systematically. ${ }^{17}$ The jumbled pictures in picture and picture strategy gave students' an opportunity to expand their ideas. Think logical means the students should arrange the jumbled pictures into a logical sequence. Think systematically means sequences of picture can help the students in arranging the right sequence and used to contextualize a story or a description of a process; (b) building. ${ }^{18}$ This strategy allowed students to have many interactions with their classmates. Due to this strategy required the students worked in a group cooperatively. It made them fun and comfortable to get the material; (c) more participation from the students. In first and second meeting, students were still in process understanding about picture and picture strategy. In the third meeting, there were some students showed their participation. Then, on next meeting the participant added. It caused the picture and picture strategy can make the class to be more alive, and learning process was enjoyable and memorable; ${ }^{19}$ (d) increasing students' communication ability in spoken as well as written in English learning ${ }^{20}$. It caused the advantages of picture and picture strategy is the teacher can gave some pictures of events then orders students to arrange it become a good chronological story. Based on the chronological story, students should create a recount text. So, the teacher can improve speaking and writing skill in the same time by using this learning srategy.

\section{Conclusion}

Based on the finding and discussion above, there was significant difference between students who were taught using picture and picture strategy and that of those who were not. Then, the motivation and prior knowledge of students' in the experimental group were better than

${ }^{17}$ Miftahul Huda, Model-Model Pengajaran: Isu-Isu Metodis dan Paradigmatis, (Yogyakarta: Pustaka Belajar, 2013), p. 239

18 Diana Achmad, Arifin Syamaun, Mauliza Fadhila, and Syamsul Bahri. "Picture This! Teaching Writing By Using Pictures to Junior High School Students", International Conference on Early Childhood Education, (2019), p. 360

19 Pradina, Yaumil Ainin, and Wiwik Dwi Hastuti, "The Effect of Picture and Picture Learning Model towards Science Outcomes for Students with Hearing Impairment in the Class VII", Journal of ICSAR vol.1, no. 2 (2017), p. 145

20 Siswo Sukarno, Model Picture And Picture Untuk Meningkatkan Minat Dan Prestasi Belajar Bahasa Inggris Dalam Menulis Teks Recount, Jurnal Pendidikan Kimia, vol.2, no. 1 (2014), p. 188 
control class after given the treatment using picture and picture strategy. In the case, picture and picture strategy has improved the ability of second grade students of Madrasah Tsanawiyah in Bengkulu to write recount text evidently.

Therefore, the researchers recommend that English teachers who conduct EFL writing class can use picture and picture strategy for teaching writing recount text due to its benefits discussed in this study. Also, the researchers hope that the study of picture and picture strategy effect in EFL writing class can be continued for further research and can be examined or tested for its effectiveness in other regions in Indonesia and other EFL countries. Even it is seemingly possible to develop some other studies of picture and picture strategy for other skills such as listening, reading and speaking.

\section{References}

Achmad, Diana, Arifin Syamaun, Mauliza Fadhila, and Syamsul Bahri, "Picture This! Teaching Writing By Using Pictures to Junior High School Students. "In International Conference on Early Childhood Education, 2019.

Ariningsih, Dwi, The effectiveness of using picture series to improve the students' writing skill viewed from their learning motivation, Surakarta: Sebelas Maret University, 2010

Campbell, Madeleine, and Laura González, ““'Wozu Image?"'What's the Point of Images? Exploring the Relation between Image and Text through Intersemiotic Translation and Its Embodied Experience." Open Cultural Studies, vol. 2, no. 1, 2018.

Chih-Pei, H. U., and Yan-Yi Chang. "John W. Creswell, research design: Qualitative, quantitative, and mixed methods approaches." Journal of Social and Administrative Sciences, vol. 4, no. 2, 2017.

Cohen, Louis, Lawrence Manion, and Keith Morrison, Research methods in education. London: Routledge, 2013

Danaei, Delneshin, Hamid R. Jamali, Yazdan Mansourian, and Hassan Rastegarpour, "Comparing reading comprehension between children reading augmented reality and print storybooks." Computers \& Education, 2020.

Fauzi, Adin, "The effect of edmodo on students' writing skill in recount text." International Journal of Pedagogy and Teacher Education, vol.1, no. 2, 2017.
Fitzsimmons, P., P. Harris, B. McKenzie, and J. Turbill, Writing in the Primary School Years, NSW: Social Science Press, 2003

Hakim, M. Arif Rahman, "A Research and development study to efl learners: Designing a speaking module for introvert students based on cooperative learning." International Journal of English and Education, vol. 7, no. 2, 2018.

Harmer, Jeremy, "Review of "How to teach writing"." Electronic Journal of Foreign Language Teaching, vol. 3, no. 2, 2006.

Huda, Miftahul, Model-Model Pengajaran: Isu-Isu Metodis dan Paradigmatis, Yogyakarta: Pustaka Belajar, 2013

Kremmel, Benjamin, Kathrin Eberharter, and Michael Maurer, "Righting Writing Practices?: An Exam Reform's Impact on L2 Writing Teaching and Assessment." In The Politics of English Second Language Writing Assessment in Global Contexts, pp. 122-137. Routledge, 2018 Lamiran, Sudarmaji, Strategi Pembelajaran Sekolah Terpadu: Pengaruhnya Terhadap Konsep Pembelajaran Sekolah Swasta Dan Negeri, Jakarta: Prestasi Pustakaaraya, 2011.

Loveri, Ardilla, Developing English Grammar Worksheet of Recount Text for Eighth Grade Students of SMP N 17 Jambi, Jambi: Repository UNJA, 2017.

Mukarto, Sujatmiko, S. M. Josephine, and W. Kriswara, English on sky 2, Jakarta: Erlangga, 2007.

Nunan, David, Teaching English to speakers of other languages: An introduction, London: Routledge, 2015

Pradina, Yaumil Ainin, and Wiwik Dwi Hastuti, "The Effect of Picture and Picture Learning Model towards Science Outcomes for Students with Hearing Impairment in the Class VII." Journal of ICSAR 1, no. 2 (2017): 145-149

Saputra, Andri, and M. Arif Rahman Hakim, "The Usage of Cohesive Devices by High-Achieving EFL Students in Writing Argumentative Essays." Indonesian TESOL Journal, vol. 2, no. 1, 2020.

Sukarno, Siswo, "Model Picture And Picture Untuk Meningkatkan Minat Dan Prestasi Belajar Bahasa Inggris Dalam Menulis Teks Recount", Jurnal Pendidikan Kimia, vol. 2, no. 1, 2014.

Suprijono, Agus, Cooperative Learning; Teori dan Aplikasi Paikem, $5^{\text {th }}$ print, Pustaka Pelajar: Yogyakarta, 2011

Uztosun, M. Sercan, "Writing English Language Tests (New Edition)" Eğitimde Kuram ve Uygulama, vol. 2, no. 2, 2006. 